\title{
協力動作と信頼の原則についての一考察
}

木村 政文*・鈴木 三郎**

\section{Study on Cooperated Action of Avoiding the Collision Related to the Vertrauensqrundsatz (the Principle of Confidence)}

\section{Masafumi KIMURA and Saburo SUZUKI}

\begin{abstract}
As the Cooperated action has been provided in clause 3 of 17 article in the Law of preventing collision at sea, but there is no deeply argued and commented papers which relate to cooperated action and the Principle of confidence, in Japan and the world.

It is essentially very important to find out that whether the Principle of confidence could be allowed to the Cooperated action or not at the Marine accident court, even though should not be applied at that court, because the Principle of confidence usually have to make to use in the Criminal court, except the matter of ship's collision at sea.

If it is applied instead of Cooperated action at the Marine accident court, more Marine accidents will obviously happen and occur at sea.

Nowadays, the ship has been built in high speed and large sized type, so she would be taken very long time and distance to stop completely, therefore the clause 2 of 17 article should have priority over the clause 3 of it.
\end{abstract}

Keywords : Cooperated behavior, the Principle of confidence, Criminal court キーワード：協力動作、信頼の原則、刑事裁判

\section{1 はじめに}

\section{協力動作と信頼の原則}

協力動作は、保持船が避航船の避航行為のみでは 衝突は避けられないと判断した場合に、保持船が衝 突を避ける行為を行うように認められた強行規定で ある(海上衝突予防法(昭和 52 年 6 月 1 日、法律第 62 号)を「予防法」之略す 17 条 3 項)。一方、避航 船の避航行為には作為、不作為が存在する。作為と
は避航船の避航行為は客観的には認められるが、そ れで以って衝突を回避している行為と評価するには 不十分である。しかし、それは不作為とは同視でき ない行為を意味する。また、この場合の不作為とは 避航船が全く避航行為を行っていない場合を意味す る。この何れの場合にも保持船には拹力動作が義務 づけられている。この意味から協力動作は権利と義 務の二面性を併せ持つといえる。そこで、海難審判 (以下、「審判」と略す)で保持船の協力動作が適正に

\footnotetext{
* 学生会員 神戸大学大学院自然科学研究科海事科学専攻（䎡658-0022 兵庫県神戸市東灘区深江南町 5-1-1）

** 正会員 · 神戸大学海事科学部

(テ658-0022 兵庫県神戸市東灘区深江南町 5-1-1)
} 
行われたと認められると当該保持船の受憲人の行為 は原因となると判断されず、その結果当該受審人の 協力動作についての過失は存在しないことになる。 また、同一の海難が刑事裁判(以下、「裁判」と略す) で審理されて被告人の行為に信頼の原則が認められ ると、同様に被告人の過失責任は否定又は軽減され ることになる(刎論、裁判でも協力動作の適用が考慮 されることもある)。しかし、裁判では船舶衝突事件 について、信頼の原則を実質的に認めたといわれて いる一例(漁船金比羅丸対第 18 勝丸衝突事件)を除き、 海難事件では信頼の原則を認めた判例は存在しない と思われる。

これは、信頼の原則は「具体的予見可能性が認め られない」ので行為の結果に対し責任を負わないの である。その意味で行為者には注意義務の軽減が図 られていると解しうる。他方、势力動作は行為者が 衝突を回避することに目的があるので，「具体的予見 可能性の存在が認められる」のであるから行為者は その結果に対して責任を負うと考えられる。その意 味で行為者には注意義務の軽減は図られていないと 解すべきである。それゆえに審判で受審人の行為に 信頼の原則の適用を認めると協力動作との関係で矛 盾が生じると考えられる。従って、保持船は協力動 作を行う時点では避航船の行為を十分に注意してそ の時期を見極める必要がある。

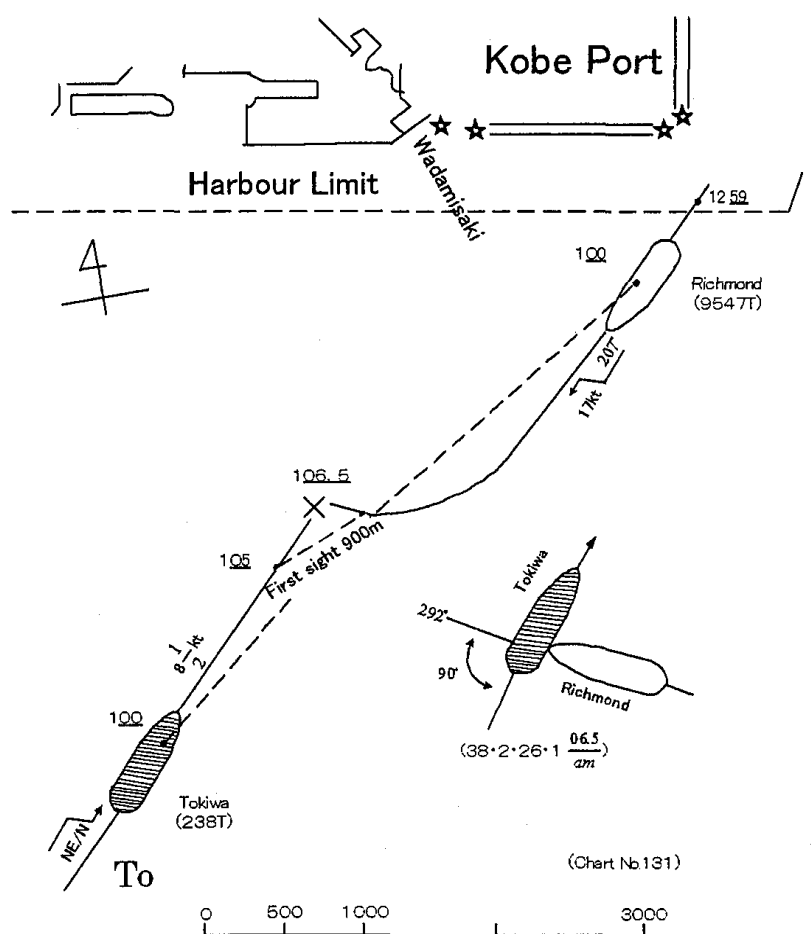

Fig. 1 Collision situation, Richimond and Tokiwa. Recorded Judgenent. 1964

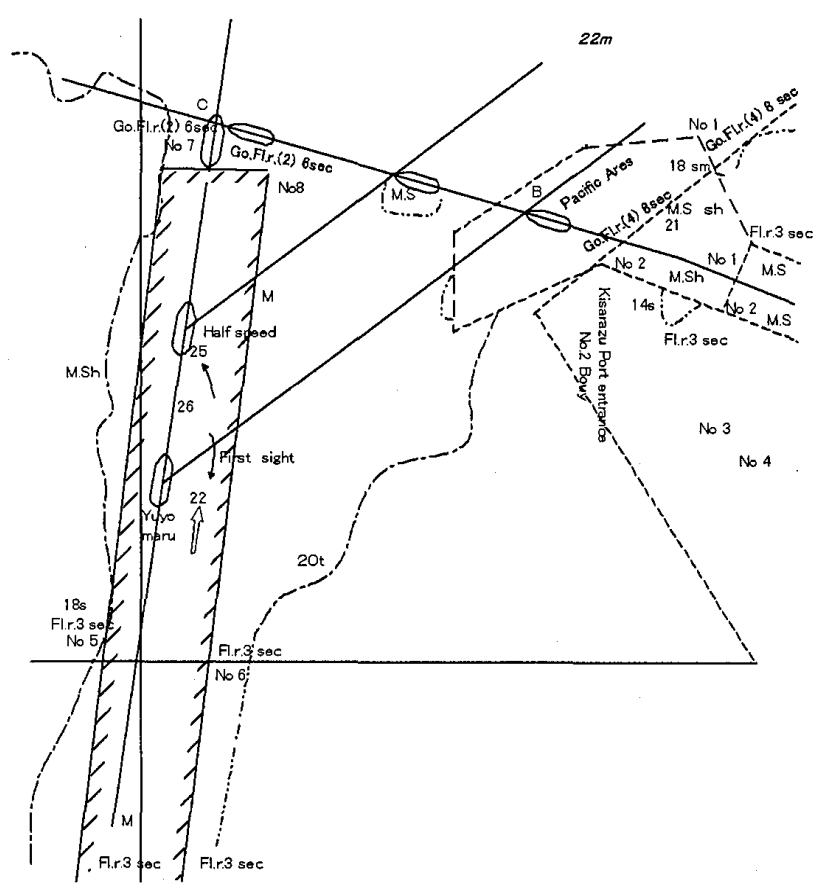

Fig.2 Collision situation. Yuyoumaru and Pacific Ares. Recorded Judgement 1975.

\section{2 信頼の原則を認めていない事例}

（1）貨物船りっちもんど丸対貨客船ときわ丸衝突 事件 (Fig. 1)

本件は、神戸港沖で昭和 38 年 2 月 26 日未明に起 きた事件である。「ときわ丸」が「りっちもんど丸」 の左舷側から衝突のおそれのある横切り関係で来航 してきており、旧予防法 19 条(現行法 15 条 1 項)に よれば「ときわ丸」が避航義務を負う義務船(避航船) であり、「りっちもんど丸」は同法 21 条本文(現行法 17 条 1 項)により針路. 速力の保持義務を負う保持 船(権利船)であったにも拘らず衝突したものである。 「ときわ丸」に重大な過失があったにも拘らず、「り っちもんど丸」の船長にも刑事責任(過失)を認めて いる。理由は、『〜従って、本件衝突の主な原因は、 〜航法に従って右転避航しなかった「ときわ丸」側 にあることは論ずるまでもない。避航船が避航しな い場合、一従って衝突の回避は専ら避航船の避航に かかっているともいえる。すなわち、保持船の側で 避航船は総て適切に避航してくれるものと信頼し、 保持義務を尽くしておればそれで注意義務から開放 されるというものではないと解すべきである』とし て信頼の原則は適用していない(神戸地判昭和 43.12.18 判時 571 号 95 頁)。

（2）タンカー第拾雄洋丸対貨物船パシフィック. アレス号衝突事件（Fig.2） 
本件は、『昭和 49 年 11 月 9 日 13 時 31 分頃雄洋 丸が中ノ瀬航路北出口至近でパシフィック．アレス 号（以下「パ号」と略す）に衝突した事件である。 本件の弁護人の主張は、雄洋丸には信頼の原則が適 用されると主張しているが判例は結論としてそれを 認めていない。即ち、被告人は雄洋丸を操船し中ノ 瀬航路をこれに沿って航行していたもので、パ号に 優先(海交法 3 条 1 項)して同航路出口至近を航行す ることが是認されていたのであり、パ号が雄洋丸の 進路に進入してくるおそれは著しく少なかったから 被告人としては、パ号が右出口至近の所に入ってく ることはないものと信頼して航行することができ〜 被告人が「臨機の措置」をとるべき義務は「信頼の 原則」の適用により免除されるから被告人には過失 は存在しないと主張している一省略一雄洋丸が、パ 号により進路を妨げられない船舶(保持船、権利船) であることを前提とする弁護人の主張はその前提を 欠くものであるとし一省略一本件は、信頼の原則を 適用すべき事案であるとは認められないので弁護人 の主張は採用しない。さ裁判所は判断している（横 浜地裁昭和 54.9.28 刑裁月報 11 巻 9 号)。

\section{3 信頼の原則を認めているといわれてい}

\section{る事例 (Fig.3)}

金比羅丸対勝丸事件の第 2 審判決がその例である。

(1) 第一審姫路簡裁の裁決(信頼の原則を認めてい ない)

被告人は、昭和 63 年 12 月 20 日午後 7 時 45 分頃、 金比羅丸を操船して家島港内の漁船船溜りを漁場に 向けて出港し東防波堤灯台を右舷正横に見た地点を

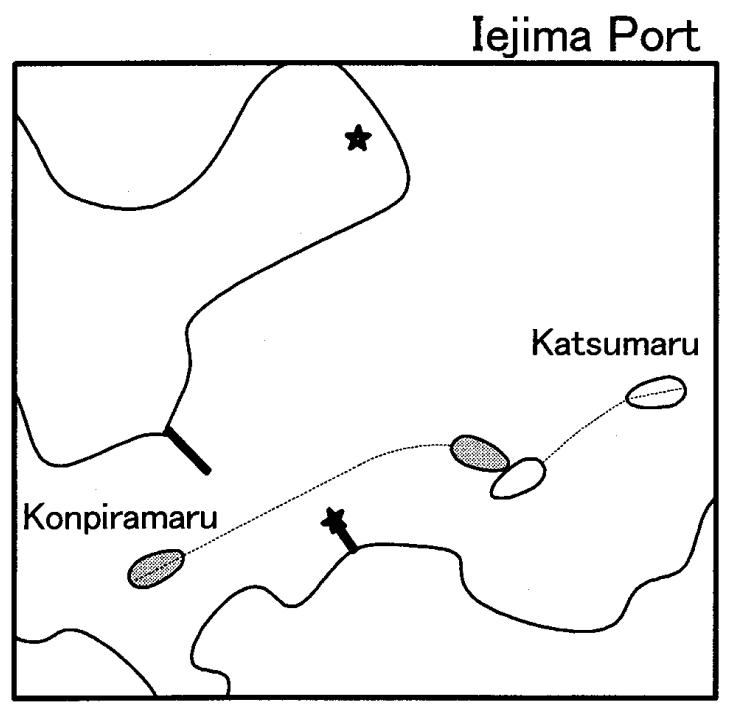

Fig.3 Assumed Collision's situation Konpira and Katsumaru
通過後に進路を右方に変更しようとしたが(当時速 力 11 ないし 16 ノット)、進路前方から予防法の航法 に違反して(家島港入口の東西両防波堤間は予防法 9 条 1 項にいう「狭水道」に当たると認定されている)、 しかも無灯火のまま約 10 ノットで向かって航行し てきた勝丸に気付かず船首を勝丸の右舷中央部付近 に衝突させ、一省略一往来の危険を生じさせると共 に勝丸の乗組員に負傷を負わせたという事案である。 尚、金比羅丸の進路方向には勝丸以外の船は存在し なかった模様である。

原審(姫路簡裁平成 3.7.24 判決) は被告人(金比羅 丸)に減速及び見張り不充分の過失があったとして 罰金 4 万円の有罪を言い渡した。

（2）第二審大阪高裁の裁決(信賴の原則を認めてい るといわれる)

大阪高裁は、速力に関する事実認定のほか、次の理 由で原判決を破棄し無罪を言い渡した。

破呆理由

(1)本件衝突時における視認距離は船首間約 22 メ一 トルであって、これを約 30 メートルとした原判決 の認定もそれが両船首間の距離を示すものであれば 誤りである。従って、両船首間の距離が約 22 メ一 トルに接近するまでの間、勝丸の視認は困難であっ たというべきであるから、原判決の指摘するような 被告人の見張りが不充分であったということはでき ない。

(2)また、速力の点については、天候の良い本件当日 の金比羅丸の航行速力を以って責めるべき速力だと いうことはできない。一省略一法律の定めた航法に 違反し無灯火の勝丸が、しかも全速力で向かって来 ることまで予想して極端に減速、徐航する義務はな いというべきである。却ってこうした減速は港口付 近の船舶の渋滞を招くもとになり別の危険をもたら すことになりかねない。

(3)以上の如く被告人には、公訴事実にある速力違反 及び見張り不充分を内容とする注意義務違反は認め られないとしている(大阪高判平成 4.6.30 判夕 831 号)。

\section{(3) 考察}

(1)について、確かに夜間での勝丸の発見は困難で あったかもしれないが、そうであるからといって勝 丸の発見が不可能であったとはいえないと解される。 これは原審(姫路簡裁)がこのことに関して金比羅丸 側に見張り不充分だとしていることからも伺える。 当時の天候は良好であったことからこの点について 
は金比羅丸が見張りについての注意義務を充分に尽 くしていなかったことが考えられる。亦原審は両 船首間の距離を 30 メートルと認定していたが大阪 高裁は簡単に 22 メートルと決めている。勿論、海 上保安官の実況見分によるものであるが、何れの船 首間の距離が正しいかは疑問である。ここで考慮す べきことは多数の証人を喚問していながら何故に 22 メートルと決定したのか、判例を閲覧する限り合 理的根拠を見出しえないからである。尚、当時天候 は良好であったと認めているのであるから、両船首 間の距離は 30 メートルと認定するほうが合理性が 担保されるのではなのかと思われる。

(2)について、勝丸が夜間航行の禁止に反し、しか も無灯火で航行したことは、あるまじき行為である。 しかも当時 6 ノットの速力で港口付近を航行するこ とも批難されるべき行為ではある。その点、金比羅 丸も当時 10 ノットの速力で航行中だったので同様 の批難は免れない。亦、当港の出入口付近は無灯火 の漁ろう中の船舶もいるとされていることからすれ ば、金比羅丸としては、仮に勝丸だけが当時付近に 存在していたとしても、それを以って見張りを疎か にしてもよいとする理由にはならないと考える。尚、 判例(大阪高裁)は、「金比羅丸は勝丸が全速力で向か って来ることまでも予測して減速、徐航の義務がな いし、」減速は港口の渋滞を招くし別の危険をもたら すと論じているが、この「」内の表現がまさしく 最高裁判所が信頼の原則を認めた中心的な表現部分 である(最判昭 41.12.20 刑集 20.10.1212、最判 42.10.13 刑集 21.8.1097)。しかし、判例を精読する 限り金比羅丸の船長は、港口付近では無灯火の漁船 が存在することも認識していた(但し、衝突した事例 は記憶にないと述べている、判例夕、831 号 243 頁,1994.2.1)のであるから勝丸が無灯火のままで、全 速力で向かってくるであろうことを予測すべきであ ったと判断することも可能である。この点、大阪高 裁は「安全な速力」を灯火表示船を認めた場合、そ の船舶との衝笑を回避できる程度の速力をいうもの と解するのが相当であるとしているがこの点は疑問 に思う。港口付近では灯火船のみを「安全な速力」 の判断の客体とすることは余りにも狭義の解釈だと 思われるからである。この「」内の点は大阪高裁 に対しもっと「船舶の海上交通」についての理解が あって欲しいと考えるし、また、「減速は港口の渋滞」 を招くとしている点は現実には考えがたいと思われ る。

（3にについて、金比羅丸には「注意義務違反は認め られない」と結論付けているが、その理由に合理性
を見出すことができない。大阪高裁の裁判官は、勝 丸が「夜間航行禁止の身分を有しながら、しかも無 灯火で航行していた事実」は著しい不当運航の行為 に該当すると判断したものとも伺える。本件衝突事 故は両船に帰責事由があると思われるので、勝丸の 当該行為と金比羅丸の行為とを比較考量して、いわ ゆる「責任割合分担」を決めて結論を出すべきでは なかったかと考える。いずれにしても金比羅丸の見 張りについての注意義務は免れないと思われる。大 阪高裁の判決は事実認定の誤りがあると考えるので、 最高裁判所に上告すべきであったと考える(刑訴法 411 条 3 号)

\section{4 海難審判と刑事裁判の適用の相違}

動力船が横切り関係で航行中、衝突事件が発生す ると審判では避航船に対し避航行為が適切であった か否か(予防法 15 条 1 項)、他方、保持船に対しては 協力動作(同法 17 条 3 項)の履行が適切であったか否 かが審理される。従って、審判では協力動作が問題 となる。

裁判では、同一事件が保持船の被告人の行為に対 し信頼の原則が認められるか否かについて審理され ることにもなるが、協力動作の履行が適性であった か否かについても審理されることもある。一般には、 弁護人は協力動作よりも信頼の原則が立証しやすい と思われるので、信頼の原則の適用を主張して被告 人の弁護を行っている。その理由は弁護人としては、 協力動作が当時の状況に照らして適切な行為と解さ れるかについては、避航船との兼ね合いから立証が 困難を伴うことが多いと判断されることにあると思 われるからである。従って、弁護人は被告人には実 質的且つ客観的に信頼の原則を適用しうる状況にあ ったと主張して、しかも被告人には「それ以上の注 意義務を課すことは苛酷である」と弁明することに なろうかと思われる。

審判で信頼の原則の適用を是認することになると 衝突の結果発生の予見可能性を否定することになる し、結果の責を負わないことになるのであるから、 そこに注意義務の軽減が認められることになる。す ると結果として予防法 5 条の「常時適切な見張りを 為す行為」を否定することにもなる。見張り行為は 航海中及び停泊中を問わず「事故を防止するうえで 極めて重要な業務の一つ」と称されているのである。 従って、信頼の原則の適用は結果として衝突(事故) の発生を呼び込むことになると思われる。 


\section{5 予防法 17 条 2 項と同条 3 項の適用に ついて}

（1）予防法 17 条 2 項は、船舶の大型化、高速化及 び近代化に伴い、保持船は避航船が「適切な避航動 作をとっていない」ことが明らかになったと主観的 (ここでは客観的要素は必要でないと考える)に判断 したならば、直ちに回避動作への着手が可能となる のに対し、3 項では保持船が「避航船の動作のみで は避航船との衝突を避けることができない」と判断 （主観的、客観的要素が必要である）した場合は、協 力動作をとらなければならない。

（2）文意から 17 条 2 項は任意規定で、 3 項は強行 規定である。しかし、2 項を解釈する上で注意す心゙ きことは、保持船には衝突を回避する為には積極的 な早期の行動を要請していると解すべきである。そ のように解することは 8 条の趣旨「船舶は〜衝突を 避ける為の動作をとる場合は〜十分に余裕ある時期 〜躊躇わずにその動作をとらなければならない」に も適合すると考えられるし、刑事裁判でも横切り状 態では予防法 17 条 2 項を積極的に履行し衝突の防 止に努めるよう判示している((上記 $2(イ)$ 判例、保持 船は避航船が全て適切に避航してくれるものと信頼 し保持義務を尽くしていればそれで注意義務から解 放されるというものではない)）。立法論的には 2 項 を強行規定とすべきであると解されるが、 3 項との 整合性を保つことができなくなる、協力動作の規定 が今後も必要であるかは疑問に思はれる。協力動作 は緊急行為(予防法 38 条 2 項)の範疇に含めてその旨 の措置をとるべきではないのかと思われる。

（3）保持船が協力動作(予防法 17 条 3 項)を行った 時点で、避航船は避航の義務を免れることはできな い。このことは、避航船が保持船の協力動作を期待 して避航義務を尽くさない危険な状態を作り出すこ とにもなるし、本来の避航船の避航義務を、保持船 にその責任の転換を強いる結果ともなるからである。

\section{6 早期回避動作と信頼の原則}

保持船は、避航船が避航動作や他の適切な動作を とっていないことが明らかになったと判断した場合 には、保持義務から早期回避動作への行為の転換が 可能となる(予防法 17 条 2 項)。しかし、この時点で 保持船に信頼の原則が認められるのか一応問題とな りうるが否定するのが妥当であると解する。信頼の 原則の成立要件は、単に形式的に信頼関係にあれば
よいのではなく、避航船の避航行為の客観的状況と その行為の信頼関係が寒質的に担保され、しかも合 理性の存在が必要とされるからである。しかし、こ の時点では未だ信頼の原則を判断する前提条件であ る避航船の避航態度が信頼の原則を認めるまでに到 っていないこと、環境条件「夜間は小型船、漁労中 の船舶は規定灯火を遵守しているとは限らないし、 強風、潮流等の影響で浮標等も移動していることも ありうる」また、自然現象「海潮流、風向、風力等」 も無視できないし、避航船との距離も信頼の原則に 着手するに適応した状況にないと考えられるのであ る。それらを総合的に判断して早期回避動作(予防法 17 条 2 項)の時点で信頼の原則を考慮することは不 可能であると解すべきであるし、亦その必要性に乏 しいと考える。

\section{7 おわりに}

海難の原因を探求するのに「信頼の原則」は適用 すべきではないと考える。審判では海難の原因の探 求には「技術的な探求」を要請されており、「運航に 関する業務上の過失」の有無が判断されているので あり、そこには規範的評価はなされていない。裁判 では「信頼の原則」は船舶の衝突発生時の具体的事 情を考慮した具体的予見可能性を基にした責任判断 がなされるのであり、具体的に予見可能であったな らば、結果に対して被告人の注意義務違反が認めら れる業務上過失責任が科せられることになる。

次に、協力動作(予防法 17 条 3 項)を保持船に対し 積極的に励行せしめたり、また、審判の審理においい ても積極的に判断することは、海難がより増加する ことにも関わってくると思われる。協力動作は事実 行為であるが、これを行う時期については非常に困 難であるといわれている(協力動作の時機は、早きに 失するよりも遅きに失するほうが良いとされてい る。(高塚裕著、予防法の実務的解説、65 頁その他) しかし、この見解が妥当でないことは既述 $(5)$ した 通りである。

そこで今後は、早期回避動作を励行すべきではな いかと考える。之に反論する見解は、「若し、早期動 作を早く行えば、丁度その時点で避航船が避航行為 を行ったら衝突の蓋然性が極めて濃厚である」と主 張するであろうが、このような状況を形成する前に 保持船は回避動作に着手すべきであると考える。

最後に懲戒(裁決) と信頼の原則及び協力動作との 関係を検討する。1で論じたように、信頼の原則は 
行為者の「注意義務の軽減」を認めうるので、行為 の結果に対する「責任も軽減」されると解し得る。 それ故、懲戒も、「責任に対応した」不利益を行為者 に科しうるものと考えられる。しかし、懲戒は審判 で審理され言い渡しが行われるが、信頼の原則は裁 判で審理されるだけである。しかし、裁判でも海難 の原因の解明は行われるので問題はあるけれども、 処罰(懲戒、刑罰)の緩和は認めるべきであると考え る。

協力動作は「注意義務の軽減」は図られていない ので「責任の軽減」も行われない。そこで、懲戒の 緩和は認められないと結論しうるのであるが、厳し い懲戒を科すことは「海難の防止」の点から大いに 疑問である(㛜しい懲戒が必ずしも海難の防止に寄 与していない)。従って、海難審判法の「海難の発生 の防止に寄与する」(審判法 1 条) 目的と理念からす ると政策的には懲戒の緩和は必要であろうと解し得 る。しかし、海難の「原因の解明は厳格」になす心゙ きである。海難の原因が不明であれば、その防止に 施しようがないからである。

\section{参考文献}

団藤重光：刑法綱要総論、有斐閣、1970、p.334

団藤重光：刑法綱要各論、有斐閣、1970

大塚仁 : 刑法総論、有斐閣、1981、p.203、p.214

大塚仁 : 刑法各論、有斐閣、1981

西原晴夫 : 交通事故と信頼の原則

渥美東洋 : 刑事訴訟法、有斐閣、1982、pp.368～

佐藤功：日本国憲法、有斐閣、1970

佐藤幸治 : 憲法講座 5 第 3 版

小早川光郎：行政法(上)、弘文堂、1999

藤崎道好 : 海上衝突予防法、成山堂、1974、p.320

福井淡 : 海上衝突予防法、海文堂、2004、pp.70～ 前田雅英：刑法総論講義、東京大学出版会、1994、 p.403、p.413

福田平・大塚仁 : 刑法の基礎知識(1)、有斐閣、1964 曽根威彦 : 刑法の重要問題総論、成文堂 海上保安庁監修：海上衝突予防法の解説、海文堂、 2004、pp.67〜

笠原包道：レーダー航法、海文堂、1977、pp.159 高等海難審判庁監修 : 海難審判庁裁決録、海難審判 協会、 1964

高塚裕 : 海上衝突予防法の実務的解説、成山堂 $1972 、$ p.65

西田典之、山口厚 : 刑法の争点、有斐閣、2000、p.76 